\title{
GEOMORPHOLOGICAL INFORMATION SYSTEM: PHYSICAL MODEL AND OPTIONS OF GEOMORPHOLOGICAL ANALYSIS
}

\begin{abstract}
P. Mentlík, K. J e d li čka, J . M inár, I. B a r ka: Geomorphological information system: physical model and options of geomorphological analysis. - Geografie-Sborník CGS, 111, 1, pp. 15-32 (2006). - The paper has two main aims. Firstly, to postulate a physical geodatabase model of a geomorphological information system based on the already existing logical geodatabase model. Secondly, to define processes of geomorphological analysis based on the physical geodatabase model. The structure of the physical model follows the logical model and is divided into three parts: adopted layers (hydrology, geology, topography and others), basic layers (elementary forms, digital elevation model and derivatives, documentation materials, genetic groups of landforms, morphodynamic phenomena, basin based features and geomorphic network) and special layers (morphostructural analysis, comprehensive geomorphological analysis and so on). The geodatabase modelling methodology was used for developing the physical geodatabase model. The geomorphological analysis is based mainly on the layer of elementary forms (defined according to their morphology and morphometry) and the derived layer of morphogenetical forms (determined by genesis of landforms). The traditional methods of geomorphological mapping and also more recent concepts of geomorphological analysis were used. The concept is presented in the context of research in the surroundings of Prášilské jezero (lake) in the Sumava (Mts.). ESRI products were used to carry out the project.
\end{abstract}

KEY WORDS: geomorphological information system (GmIS) - geomorphological analysis - geomorphological mapping - glacial forms.

This paper has been created in the framework of the Czech-Slovak Intergovernmental Scientific-technical cooperation project: 'Geomorphological information system as a base of environmental applications' number 116. Research has been supported by the grant of the Czech Academy of Science of the Czech Republic number KJB300460501 (PM), by the Research Plan MSM 4977751301 (Ministry of Education, Youth and sports, Czech Republic; KJ) and by the grant of the Scientific Grant Agency of the Ministry of Education of the Slovak Republic and the Slovak Academy of Science (1/1037/04; PM, IB and JM).

\section{Introduction}

Geomorphological Information System (GmIS) as a special type of geographic information system (GIS) focused on collecting, maintaining and analyzing geomorphic information is a very good tool for geomorphological analysis. This idea has been mentioned by several authors (e.g. Barsch, Dikau 1989, Dikau 1992, Minár 1996, Kusendová 2000, Voženílek et al. 2001). However, some problems remain which we would like to solve.

The primary idea of GmIS is not based on a special technical solution. In fact, only common GIS tools are used here. However, the configuration and connections of the thematic layers (particularly the position of the layer of elementary forms as a base of the system in our case) and also the structure of the database are characteristic features of GmIS. 
One of the goals of this paper is to present an example of implementation of geomorphological analysis into Geomorphological Information System. An example from the surroundings of Prášilské jezero (lake) in the Sumava Mts. (the Czech Republic) is presented here (Fig. 7, 8, 9 and 10).

Description of the creation of the physical model of a geomorphological database is the other goal. This model is a necessary condition for implementing the geomorphological analysis in GmIS environment. However, before this, it is necessary to introduce a logical model of GmIS database. In connection with defined goals, two aspects of GmIS can be distinguished: geomorphological and technical.

From a geomorphological point of view GmIS is defined as an environment suitable for an analysis of georelief (mainly geomorphological analysis) in an exact way and also for comprehensive administration of geomorphological data and/or data useful for geomorphological research.

From a technical point of view, GmIS is, however, an environment providing storage and management of geomorphological data and also possibilities for particular predefined analysis of the data. The uniform delimitation of geomorphological units and some predefined techniques of geomorphological analysis should be an integral part of the system.

The core of geomorphological investigation in GmIS is geomorphological analysis based on the fundamental concept of geomorphology which says that activities of geomorphological processes are explicitly represented in the shape of the georelief. This means that analysis of georelief provides correct information about the origin and development of a landscape as well as relevant data about activities of recent and present-day processes. However, the exact methodological procedure of geomorphological analysis has not been clearly defined yet, although some authors (e.g. Urbánek $2000 \mathrm{a}, \mathrm{b}$ ) postulate particular steps of the analysis. It is possible to transform and renew Urbánek's concept and to use it in GmIS. This provides an environment for geomorphological analysis because it is possible to manage a huge amount of information and to deal with special operations which provide exact data. The significance of this approach is increasing because of the number of new methods and techniques of research being used in geomorphology. An example could be the progress of GIS and GPS techniques as well as the application of various methods using results of research in physics, chemistry or biology (various dating methods, scanning electron microscopy, pollen analysis etc.).

The following important features of geomorphological analysis can be defined in GmIS:

Precision: there are two things in geomorphological analysis which should be particularly precise: firstly, the definition of the geomorphological forms should be as precise and as clear as possible. Secondly, it must be possible to repeat all the steps of a particular analysis again.

Flexibility: two aspects of flexibility of geomorphological analysis can be defined:

- geomorphological analysis should be open to various inputs (analysis providing extra information about particular geomorphological forms),

- it is also necessary to enable analysis in various types of georelief. This means providing methods of definition of extra categories of geomorphological forms and specifications for a particular user.

Stability: the technical background of geomorphological analysis should be as stable as possible. It is necessary to postulate the main steps of the 
analysis in the physical model of Geodatabase of GmIS and to connect it with other parts of GmIS.

Generally it is possible to say that geomorphological analysis in GmIS is a process for systematically increasing knowledge about georelief. All steps of the process should be exactly defined and reversible (it must be possible to repeat a particular analysis again). The main aim of the geomorphological analysis is to postulate a hypothesis (ideally theory) of the genesis of georelief.

\section{Outline of logical model of geomorphological database}

The logical model can represent a user's point of view of the comprehensive geomorphological database - the core of GmIS. Our model consists of three main parts, which are composed of layers or groups of layers (adapted from Minár et al. 2005):

Adopted layers - layers which have been taken from external sources, such as hydrology, geology, topography and others.

Basic layers - layers which are created by a geomorphologist; by field survey or by derivation from adopted layers or using them in combination. This group is composed of layers of elementary forms ${ }^{1}$, a digital elevation model (DEM) and its derivatives, documentation materials, genetic groups of landforms, morphodynamic phenomena, basin based features and geomorphological network.

Special layers - layers created by special geomorphological analysis, such as morphostructural analysis, comprehensive geomorphological analysis, geomorphologic hazard evaluation and so on.

The logical model is described in Minár et al. (2005). An ArcMap project is a way of visualizing the logical model in a computer. It is also a common user interface in which the user - a geomorphologist - works (see Fig. 1).

The physical model comes from the logical model and it is a real representation of data of GmIS in a spatial database. The physical model is closely connected to a database or to a file oriented data structure. We selected ESRI Geodatabase structure for storing the GmIS data.

\section{Physical model of geomorphological database}

The scope of this contribution does not allow the complete physical model of the database and all the algorithms of geomorphological analysis to be shown. Only the selected core components are presented. Creation of the physical model involves developing its structure and populating the structure with real data. The physical model follows the structure of the logical model, but there are exceptions which come from the limitations of the spatial database structure ${ }^{2}$. There are only two serious limitations influencing the GmIS structure: topology relations cannot be built among datasets; there can be only one level of datasets (it is not possible to create subdatasets).

1 The elementary forms are basic mapping segments of georelief characterized by maximum homogeneity (constant value) of some relevant morphometric characteristics (altitude, slope, various curvatures, ...) and bounded by discontinuity lines of some of these characteristics - see e.g. Minár (1996).

2 General description of ESRI Geodatabase can be found e. g. in Arctur \& Zeiler (2004). 


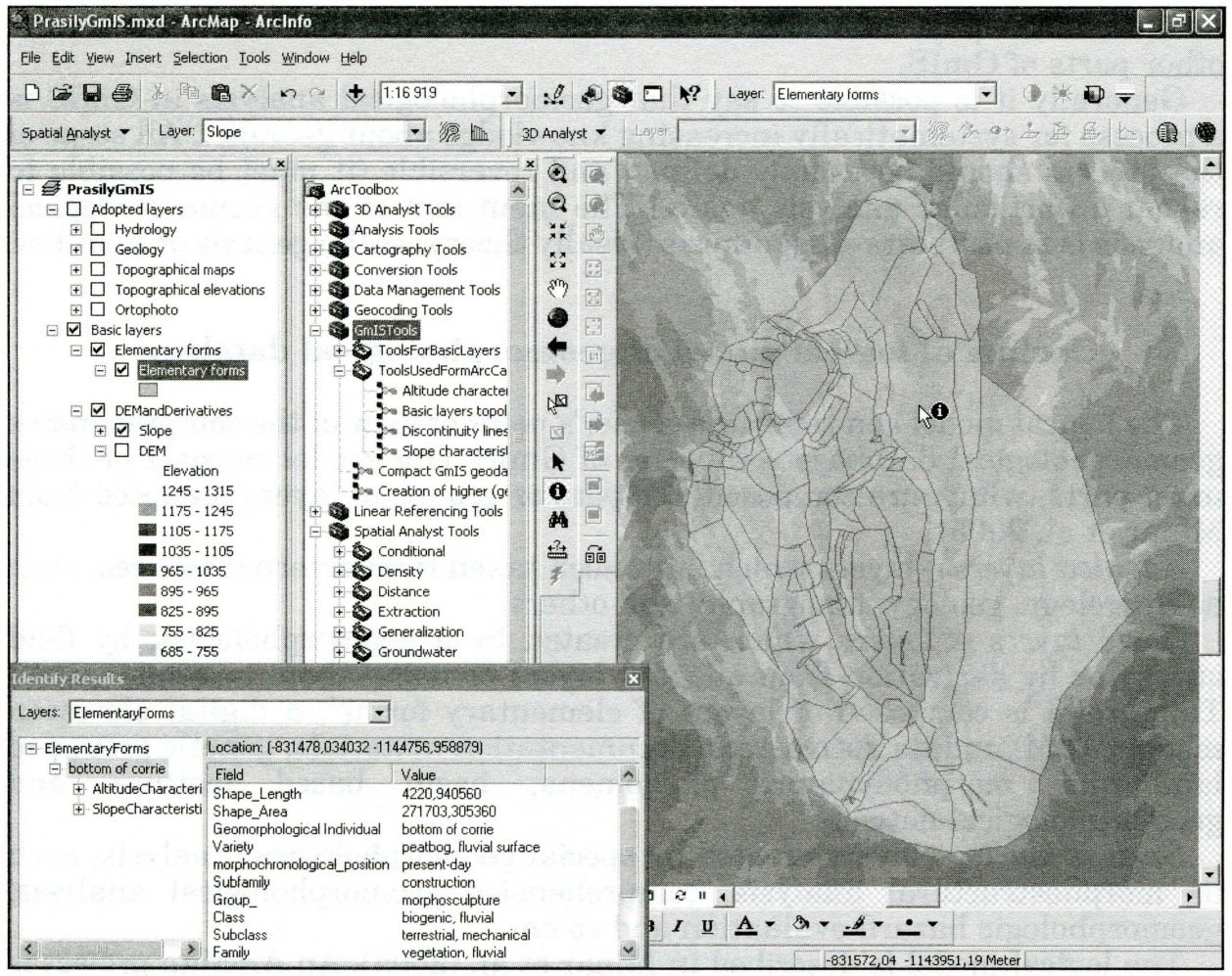

Fig. 1 - ArcMap Project reflecting some aspects of logical model. Screenshot from ArcMap 9.0; the area under consideration dealt with in this paper is presented here.

Our physical model of the geomorphological database is only divided into the dataset "AdoptedLayers" 3 equivalent to the adopted layers from the logical model, and into the dataset "GeomorphologicalLayers", where all basic and special geomorphological layers are stored. This is because it is necessary to maintain topology among them. All non spatial tables are stored in the geodatabase root directory. The symbology of ESRI reverse engineering diagrams is used in the figures displaying the physical model - see e.g. Arctur \& Zeiler (2004). The legend to this symbology is explained in Fig. 2.

Adopted layers are created and populated by converting data from external sources, i.e. external digital databases, files or scanned paper maps. These processes are common in geographical information systems (GIS) and are not described here.

The geomorphological layers dataset is the core of the geomorphological database. Its structure (without attributes) is shown in Fig. 3.

Firstly it is necessary to create DEM. Interpolation from the contour lines has been used in our case. Other raster layers, such as slope, aspect and curvatures are derived from it. Further documentation materials layers are populated from field survey.

3 All names in the geomorphological database in the figures follow naming conventions for ESRI Geodatabase, see e.g. ESRI 2005 or Jedlička (2005). For better legibility the full terms are used in the following text. 


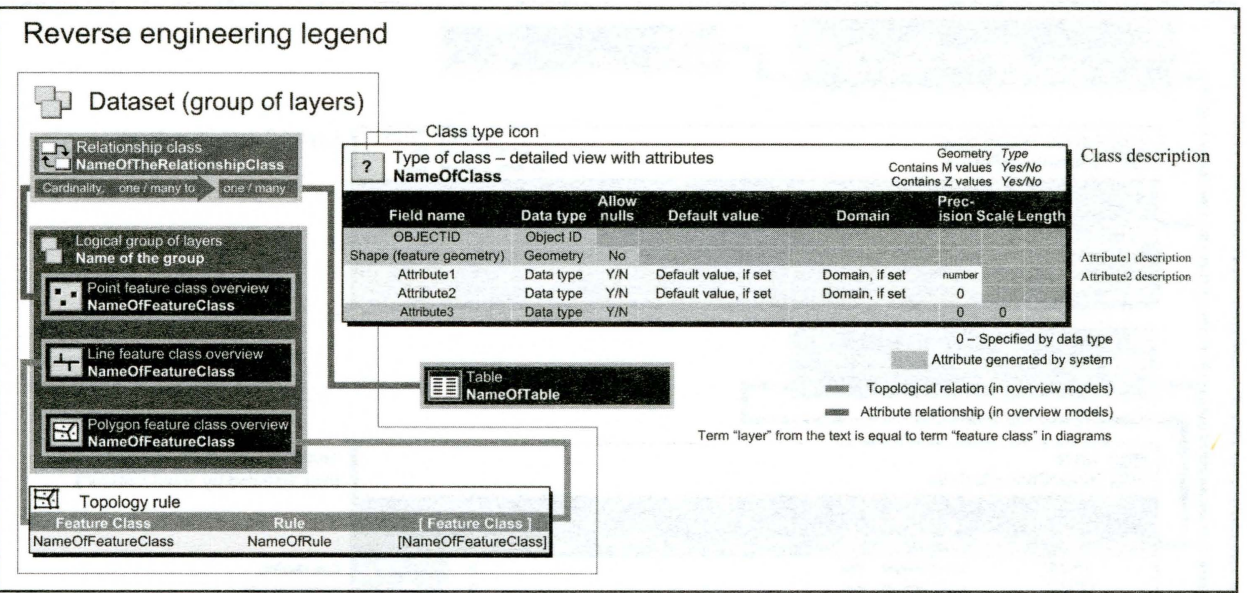

Fig. 2 - Legend of ESRI reverse engineering diagrams according to Arctur \& Zeiler (2004); created by ESRI Geodatabase Diagrammer in Microsoft Visio.

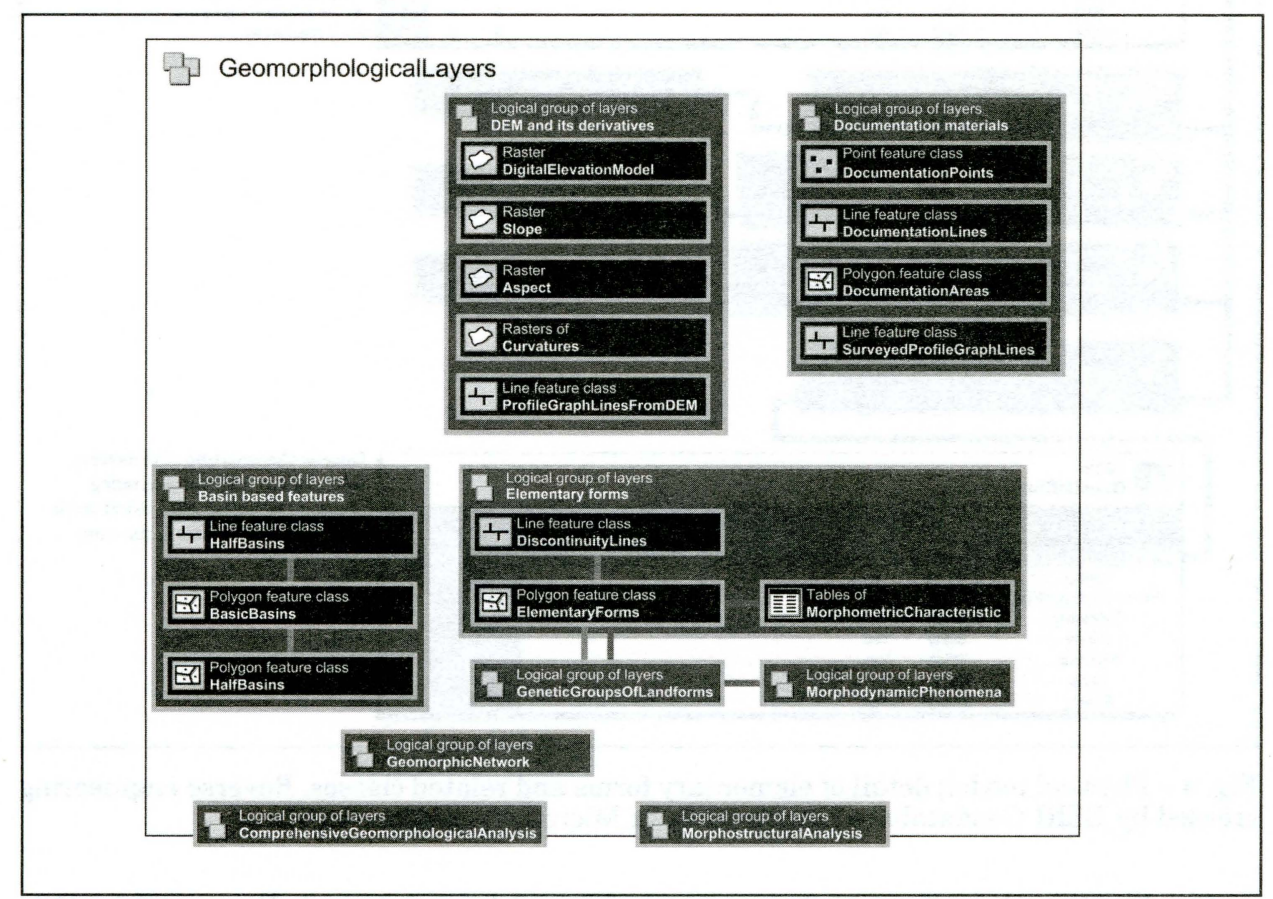

Fig. 3 - Physical model; overview of geomorphological layers. Reverse engineering created by ESRI Geodatabase Diagrammer in Microsoft Visio.

Elementary forms are created interactively from DEM and its derivatives in an ArcGIS environment and documentation materials from geomorphological mapping. Basin based features can be created using the hydrological functions of ArcGIS.

The layers of the genetic group of landforms, morphodynamic phenomena and geometric network are created furthering the process of geomorphological 


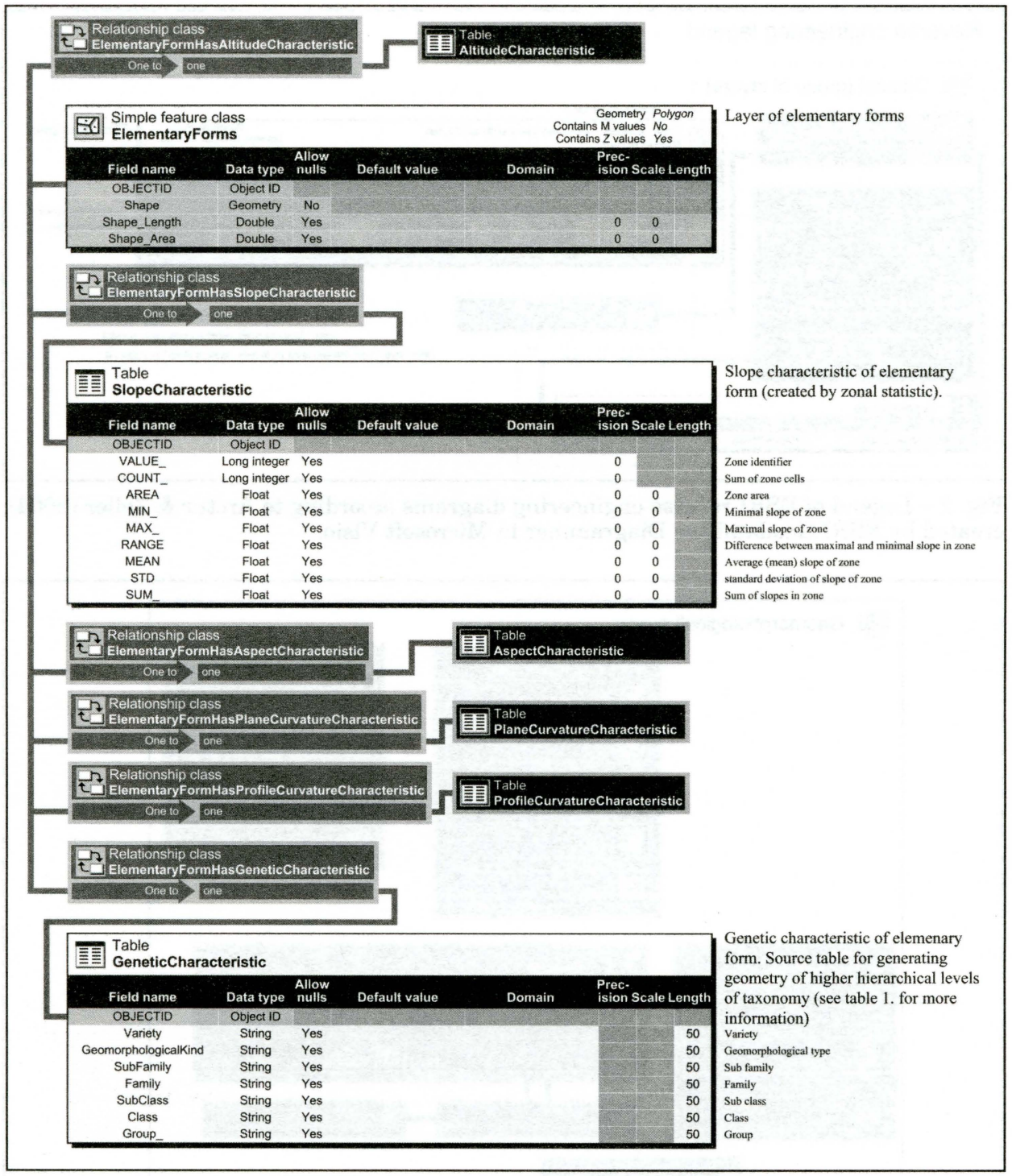

Fig. 4 - Physical model; detail of elementary forms and related classes. Reverse engineering created by ESRI Geodatabase Diagrammer in Microsoft Visio.

analysis. Creation of special geomorphological layers is not discussed in this article.

Details of the physical structure are presented in the example of elementary forms and connected spatial and attribute layers. The elementary forms are related to several attribute tables (see Fig. 4), which describe elementary forms of altitude, slope, aspect and curvature characteristics. All these related tables have the same attribute fields as the slope characteristic. These tables are created by zonal statistics in GIS. The process was automated for the purposes of GmIS (the automation is depicted in Fig. 6 and 


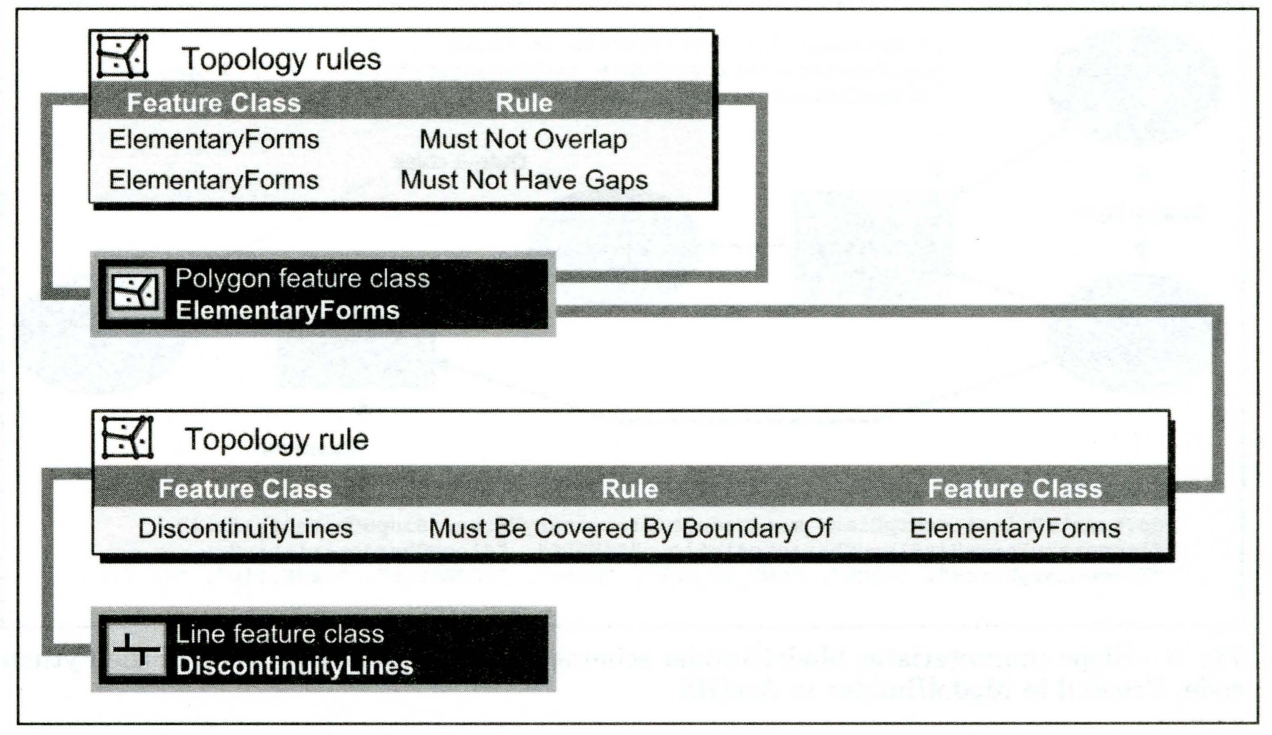

Fig. 5 - Physical model; detail of elementary forms and Discontinuity lines topology. Reverse engineering created by ESRI Geodatabase Diagrammer in Microsoft Visio.

described below the figure) and it can be run whenever the geometry of the elementary forms is changed. Then, the information in the attributes is always consistent with the geometrical representation.

The situation in the case of the table of genetic characteristics is more complicated, because operator entry is necessary. The geomorphologist has to enter information at least into the field of lowest taxonomic level (generally "variety" or "geomorphological kind"). The higher hierarchic levels can be derived automatically in the case of an existing full morphogenetic system of landforms (the rules for listing every unit of lowest hierarchical level into a higher taxon must be defined). There are also important spatial relations among layers in the geomorphological database. Most of them can be explored without special tools. The standard GIS identification and spatial query tool are sufficient. But in cases where geometry of one layer is dependent on the geometry of another layer, it is necessary to use some kind of topological tool. An example of topological relations set up in the geodatabase between elementary forms and discontinuity lines is shown in Fig. 5.

In traditional geomorphological maps elementary forms should cover the whole area of interest (the rule "elementary forms must not have gaps" is set up) and also they should not overlap, because one form describes just one "piece of land" and the spatial relation is one to one (so the rule "must not overlap" is added). If fuzzy boundaries occur, topological exception can be used. Next, discontinuity lines should spatially match the boundaries of elementary forms, so the rule "discontinuity lines must be covered by boundary of elementary forms" is added.

After the topology has been set up, the GIS environment allows the user to easily maintain spatial relationships among all layers which are involved. As is discussed above, when the database model is well developed, a lot of the geomorphological analysis steps can be performed using common GIS tools. For other cases, it is possible to create special GmIS 


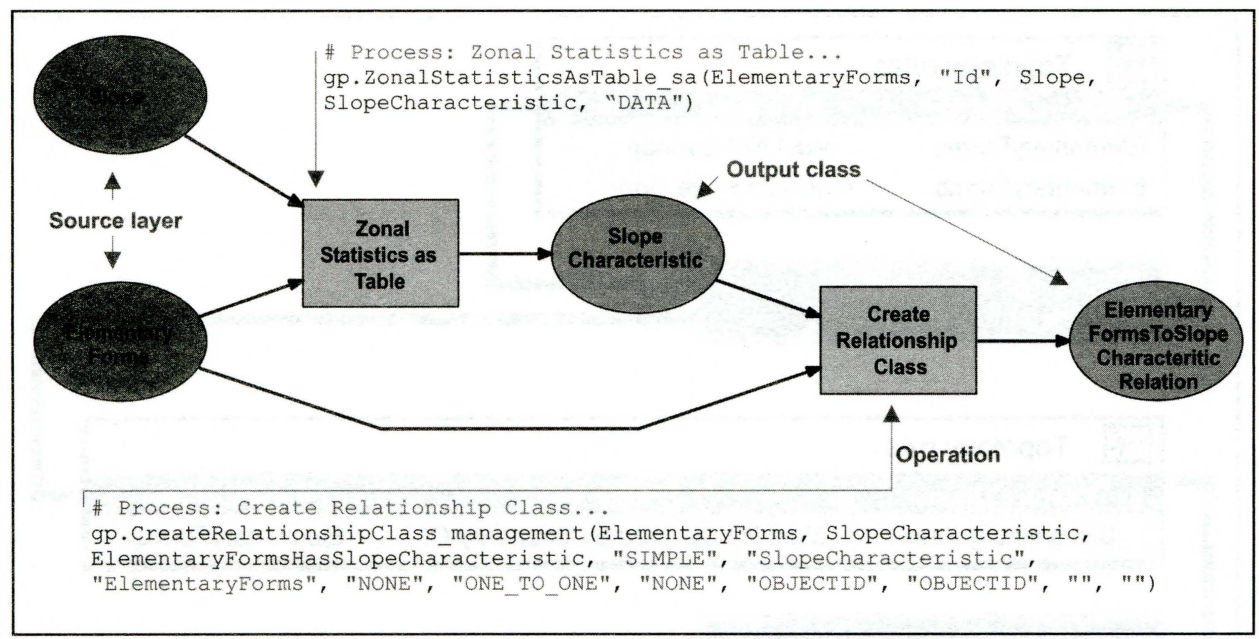

Fig. 6 - Slope characteristic; ModelBuilder scheme and example of core parts of the Python code. Created in ModelBuilder in ArcGIS.

tools, for example using ModelBuilder - a graphical user interface for Python programming language in the ESRI products. It is also possible to directly write a Python code in the classical editor. Both of these alternative entries have been used and combined during the development of geomorphological analysis tools. An example of the tool code schemed in ModelBuilder is shown in Fig. 6.

Zonal analysis (see i.e. Tuček 1998) is applied here to two source layers. Cells of raster of slopes are statistically evaluated in each zone - elementary form. Results of the analysis are stored into a "SlopeCharacteristic" table in the geodatabase. One to one relationship between slope characteristic table and elementary forms is created in the next step. Altitude, aspect and curvature characteristics are created using similar models.

\section{Geomorphological analysis}

The case study of geomorphological analysis in GmIS, which was carried out in the surroundings of Prášilské jezero (lake), is described in the following part of this article. Some theoretical and methodical problems of geomorphological analysis are discussed simultaneously.

The correct delimitation of geomorphological forms is a crucial step of geomorphological research. Although geomorphologists should investigate the surface of the Earth as a whole, very often more attention is paid to some particular parts of georelief. This is because some landforms are more significant (outcrops, planation surfaces etc.) than others (mainly different parts of slopes). Hence a unified principle for delimiting landforms (geomorphological forms) is highly important because the results of comprehensive geomorphological analysis (complex geomorphological maps or a hypothesis for the development of the area of interest) should deal with all parts of the georelief equally.

Although mainly glacial forms are presented in the area under concern, gravitation, fluvial and suffusion forms also exist there (Fig. 10). 
Table 1 - Features used for analysis of genesis of geomorphological forms with examples from the surroundings of Prášilské jezero (lake) (units used for geomorphological analysis are highlighted by the bold frame).

\begin{tabular}{|l|l|l|}
\hline Systematic unit & $\begin{array}{l}\text { Characteristics used to define } \\
\text { a particular class }\end{array}$ & $\begin{array}{l}\text { Examples of particular classes in } \\
\text { the surroundings of Prášilské } \\
\text { jezero (lake) }\end{array}$ \\
\hline Group & General geomorphological factors & Exogenetic forms \\
\hline Class & $\begin{array}{l}\text { Affiliation of the geomorphological } \\
\text { agents to the partial geospheres }\end{array}$ & $\begin{array}{l}\text { Cryogenetic class (corries, } \\
\text { moraine walls, cryoplanation } \\
\text { terraces) }\end{array}$ \\
\hline Subclass & $\begin{array}{l}\text { Specification of the types of energy } \\
\text { and substratum of particular } \\
\text { geomorphological agent }\end{array}$ & $\begin{array}{l}\text { Subclasses of glacial (corries), } \\
\text { nival (nivation hollow) and } \\
\text { cryoplanation forms } \\
\text { (cryoplanation terraces) etc. }\end{array}$ \\
\hline Family & $\begin{array}{l}\text { Character of geomorphological } \\
\text { conditions and the basic } \\
\text { mechanism of geomorphological } \\
\text { process }\end{array}$ & $\begin{array}{l}\text { Family of mountain glaciers } \\
\text { forms, nival forms created by } \\
\text { nivation or snow avalanches etc. }\end{array}$ \\
\hline Subfamily & $\begin{array}{l}\text { Definition of specific } \\
\text { geomorphological processes in } \\
\text { particular family }\end{array}$ & $\begin{array}{l}\text { Accumulation or destruction } \\
\text { forms in particular families }\end{array}$ \\
\hline $\begin{array}{l}\text { Geomorphological } \\
\text { kind }\end{array}$ & $\begin{array}{l}\text { Genetically homogenous and } \\
\text { morphologically delimited part } \\
\text { of georelief }\end{array}$ & $\begin{array}{l}\text { Corries, moraine walls, dellens } \\
\text { etc. }\end{array}$ \\
\hline Variety & $\begin{array}{l}\text { Parts of a morphogenetical form } \\
\text { with different genesis }\end{array}$ & $\begin{array}{l}\text { Permanent slope erosion furrows' } \\
\text { or track of debris flows in the } \\
\text { walls of corries etc. }\end{array}$ \\
\hline
\end{tabular}

The layer of elementary forms therefore represents the core of GmIS and also the basic part of geomorphological analysis. A significant and uniform principle for delimitation of the elementary forms (Minár 1996) is very appropriate in this case. Morphological homogeneity of elementary forms is related to their genetic and dynamic homogeneity. Therefore all information which is obtained during geomorphological analysis can be connected by this layer. The other higher geomorphological individuals (composed form, geomorphic regions of higher order) are generated from this basic layer usually by defining specific attributes in the Geodatabase (Table 1 and Table 2).

The main aim of geomorphological analysis is the investigation of the genesis of georelief (Demek ed. 1972). Basically, elementary forms have homogenous morphometric characteristics and the boundaries between them are defined as discontinuities of the morphometric characteristics. More significant boundaries of elementary forms also represent the frontiers between morphogenetic forms. The definition of these boundaries is an important part of geomorphological analysis (the phase of differentiation - Table 2).

Each geomorphological individual can be classified according to its genesis. The genetic classification of georelief segments according to Minár (1996) was

4 These systematic units create the part of the physical model Table Genetic Characteristics (Fig. 5). 
Table 2 - Summary of steps geomorphological analysis in GmIS

\begin{tabular}{|c|c|c|c|}
\hline \multicolumn{2}{|c|}{$\begin{array}{l}\text { Step of } \\
\text { geomorphological } \\
\text { analysis }\end{array}$} & $\begin{array}{l}\text { Process (processes) of } \\
\text { geomorphological analysis }\end{array}$ & Output in GmIS \\
\hline \multicolumn{2}{|c|}{ Identification } & $\begin{array}{l}\text { Definition and delimitation } \\
\text { of the area of interest }\end{array}$ & $\begin{array}{l}\text { Layer presents boundary of the } \\
\text { area of interest }\end{array}$ \\
\hline \multirow{3}{*}{ 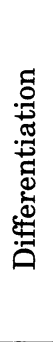 } & 1st phase & $\begin{array}{l}\text { Delimitation of elementary } \\
\text { forms }\end{array}$ & $\begin{array}{l}\text { Map of elementary forms of the } \\
\text { area of interest }\end{array}$ \\
\hline & 2nd phase & $\begin{array}{l}\text { Identification of the main } \\
\text { and obvious morphogenetical } \\
\text { forms }\end{array}$ & Primary map of georelief \\
\hline & 3rd phase & $\begin{array}{l}\text { Spatial connection of } \\
\text { elementary forms or } \\
\text { morphogenetical forms with } \\
\text { documentation points }\end{array}$ & $\begin{array}{l}\text { Assigning further information to } \\
\text { layers of elementary forms and/or } \\
\text { morphogenetical forms }\end{array}$ \\
\hline \multicolumn{2}{|c|}{ Systematization } & $\begin{array}{l}\text { Swinging system analysis } \\
\text { of georelief }\end{array}$ & Secondary map of georelief \\
\hline \multicolumn{2}{|c|}{$\begin{array}{l}\text { Analysis of present } \\
\text { day geomorphological } \\
\text { processes }\end{array}$} & $\begin{array}{l}\text { Definition of geomorphological } \\
\text { varieties which have been } \\
\text { created by present-day } \\
\text { geomorphological processes }\end{array}$ & $\begin{array}{l}\text { Map of geomorphological varieties } \\
\text { (defined by present-day } \\
\text { geomorphological processes) }\end{array}$ \\
\hline \multicolumn{2}{|c|}{$\begin{array}{l}\text { Analysis of } \\
\text { morphochronology }\end{array}$} & $\begin{array}{l}\text { Postulation of particular } \\
\text { geomorphosystems for each } \\
\text { stage of development of the } \\
\text { area of interest. }\end{array}$ & Special morphochronological map \\
\hline \multicolumn{2}{|c|}{$\begin{array}{l}\text { Summary of } \\
\text { geomorphological } \\
\text { analysis }\end{array}$} & $\begin{array}{l}\text { Creation of hypothesis for } \\
\text { development of the area } \\
\text { of interest }\end{array}$ & Clarification of attributes of layers \\
\hline \multicolumn{2}{|c|}{$\begin{array}{l}\text { Verification of } \\
\text { hypothesis }\end{array}$} & $\begin{array}{l}\text { Using various } \\
\text { (non-geomorphological) } \\
\text { methods of research for } \\
\text { verification of the hypothesis }\end{array}$ & Clarification of attributes of layers \\
\hline
\end{tabular}

adapted and then used in the surroundings of Prášilské jezero (lake) - Table 1 . The systematic units are presented by genetic attributes in the geomorphological database (Fig. 4 - table of genetic characteristics).

The process of geomorphological analysis in GmIS can be summarized as follows ${ }^{5}$ (Table 2):

Identification: definition of the area under concern. A layer representing the boundary of the area of interest is the output of this phase in GmIS.

Differentiation $-1^{\text {st }}$ phase: delimitation of elementary forms according to their morphology and morphometric characteristics (Fig. 3 - tables of morphometric characteristics or Fig. 4 - tables related to elementary forms) - the map of elementary forms of the area of interest is the output of this phase in GmIS (Table 2).

Differentiation - $2^{\text {nd }}$ phase: identification of the main and obvious morphogenetical forms according to their genesis on the taxonomic level of geomorphological kind (primary morphogenetic forms). The corries, moraine

5 The particular phases of the analysis partly concur with the steps of geomorphological analysis according to Urbánek (2000 a, b). 


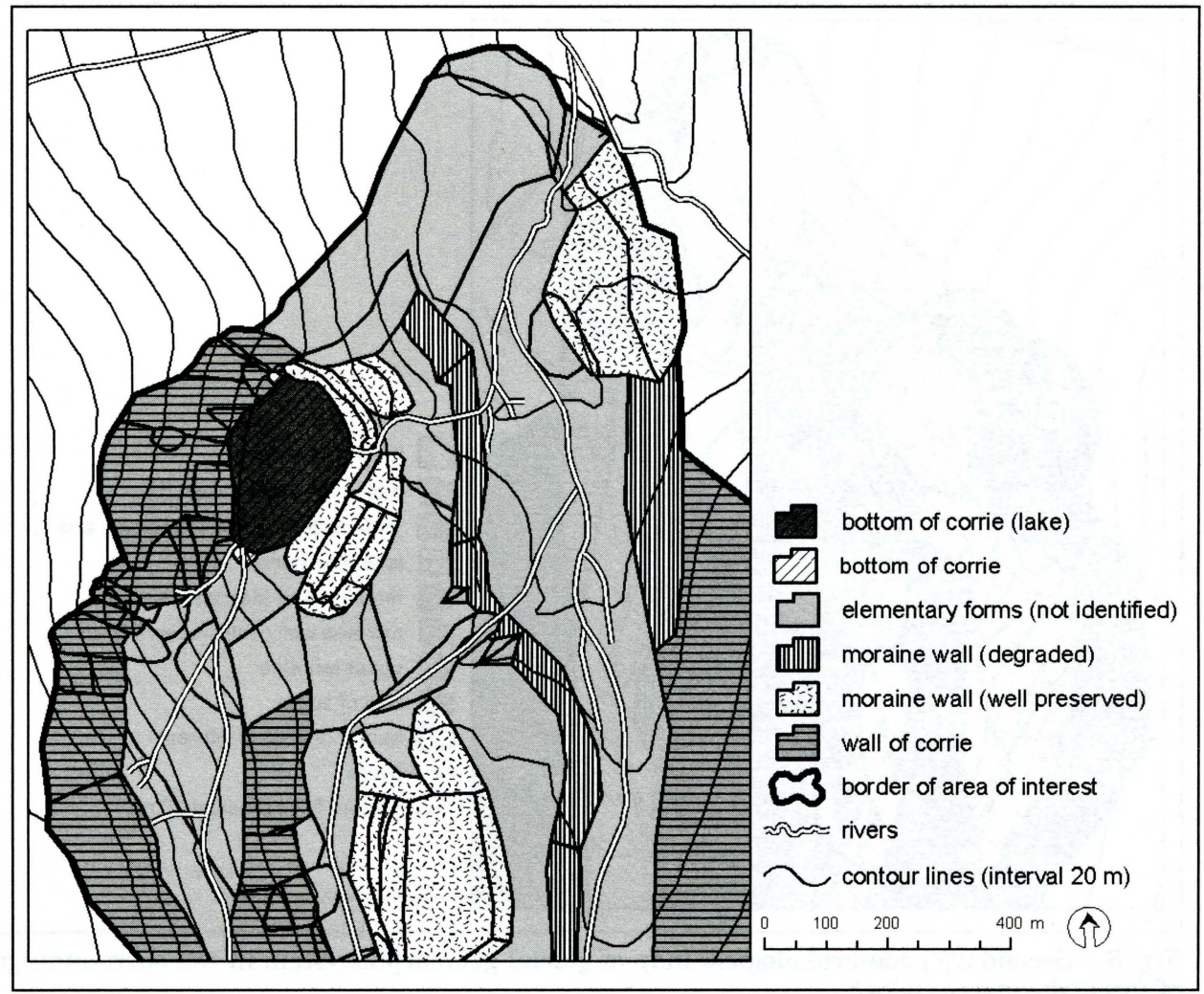

Fig. 7 - Primary geomorphological map of the glacial geomorphosystem in the surroundings of Prášilské jezero (lake).

walls and remnants of planation surfaces were identified in the surroundings of Prášilské jezero (lake) - the primary geomorphological map is the output of this phase in GmIS (Fig. 7).

Differentiation $-3^{\text {rd }}$ phase (the information flow phase): spatial connection of primary morphogenetical forms with documentation points (Fig. 3) and other specific layers (the layer of rock formations etc). These layers provide more exact information about the genesis of the particular forms.

Only morphogenetic forms were defined in this part of the analysis while other elementary forms obtain information from other layers. However, the spatial position of these forms in relation to the other, which had already been identified, was very important for the following analysis.

Systematization: reconstruction of geosystems (present-day or fossil) of the landscape. Relief in Central Europe is generally polygenetic. This very often means dealing with fossil geomorphosystems during geomorphological analysis. It is highly important to clearly define all geomorphosystems which can be found in the area of interest at this level of research. The morphogenetical forms defined so far, were used as the base of the operation. According to the relationship between the undefined forms and defined forms in the geomorphosystem, we can identify the forms which have not been defined so far. This process was carried out in consequent steps. Gradual definition of morphogenetical forms brought new information about its 


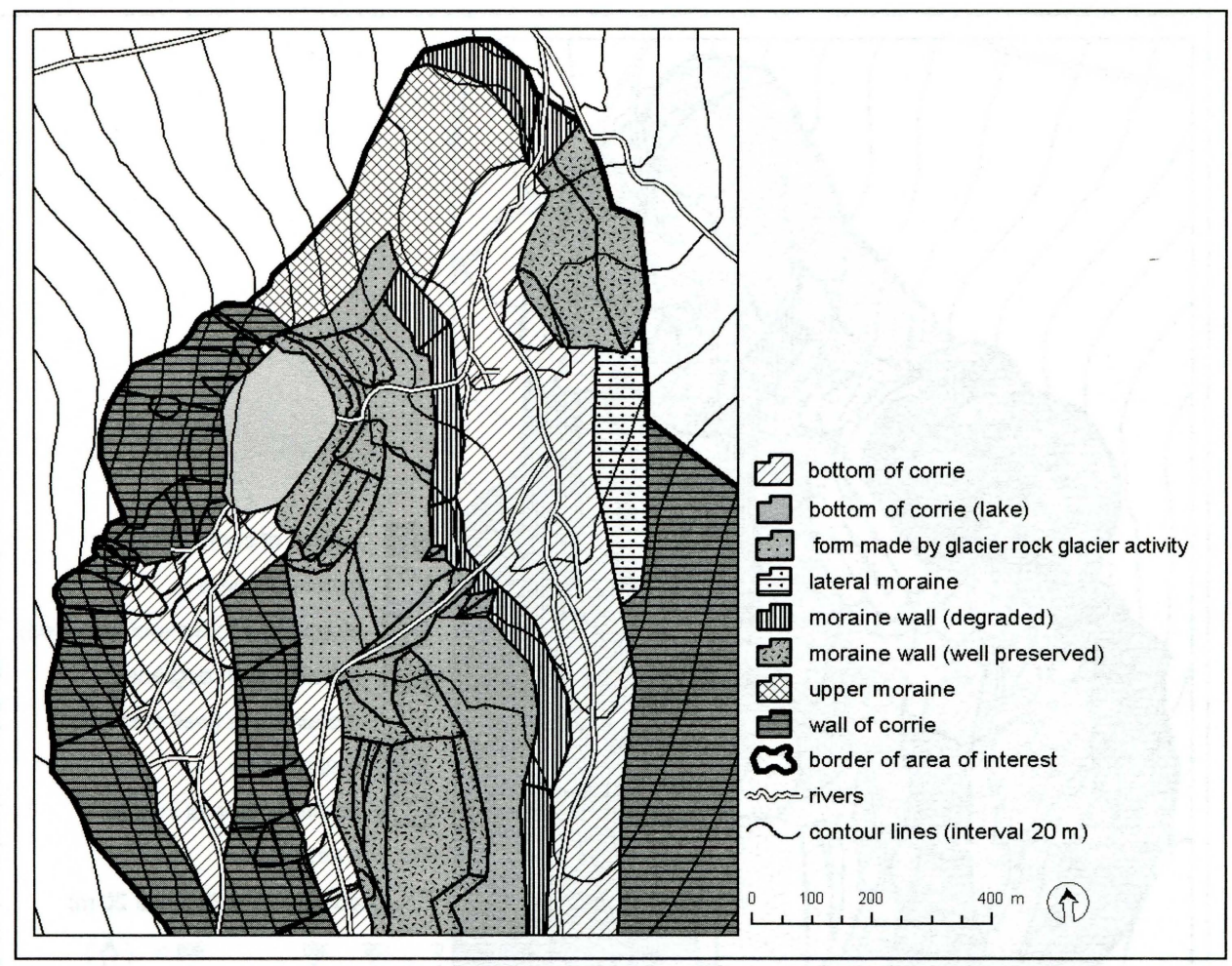

Fig. 8 - Secondary geomorphological map of glacial geomorphosystem in the surroundings of Prášilské jezero (lake) ${ }^{6}$.

neighbours (this process is called 'the swinging system analysis of georelief'). The secondary map of georelief is the output in this phase (Fig. 8). This map expresses morphogenetical forms in the area of interest and covers the whole area without any remnants of undefined elementary forms in a particular geomorphosystem. Certainly, the relevance of the identification of particular morphogenetical forms is different and these differences should be registered in the geodatabase.

Further geomorphological analysis consists of the following two steps in this stage: analysis of present-day processes and analysis of morphochronology.

Analysis of present-day geomorphological processes: the morphogenetical forms which have been defined during the geomorphological analysis so far, create the main features of the georelief in the area of interest. But these forms are seldom homogenous. The main features of georelief in our area of interest were created during the Pleistocene, when the geomorphological processes were more powerful than at present. Hence these main features of landscape have been changed by present-day geomorphological processes. These heterogeneities can represent geomorphological varieties - parts of morphogenetical forms with a different genesis (Table 1). For example, the corries disturbed by tracks of debris flows or 'permanent slope erosion

6 All glacial geomorphological forms (each part of glacial geomorphosystem) in the surroundings of Prášilské jezero (lake) are identified in this phase of geomorphological analysis. 


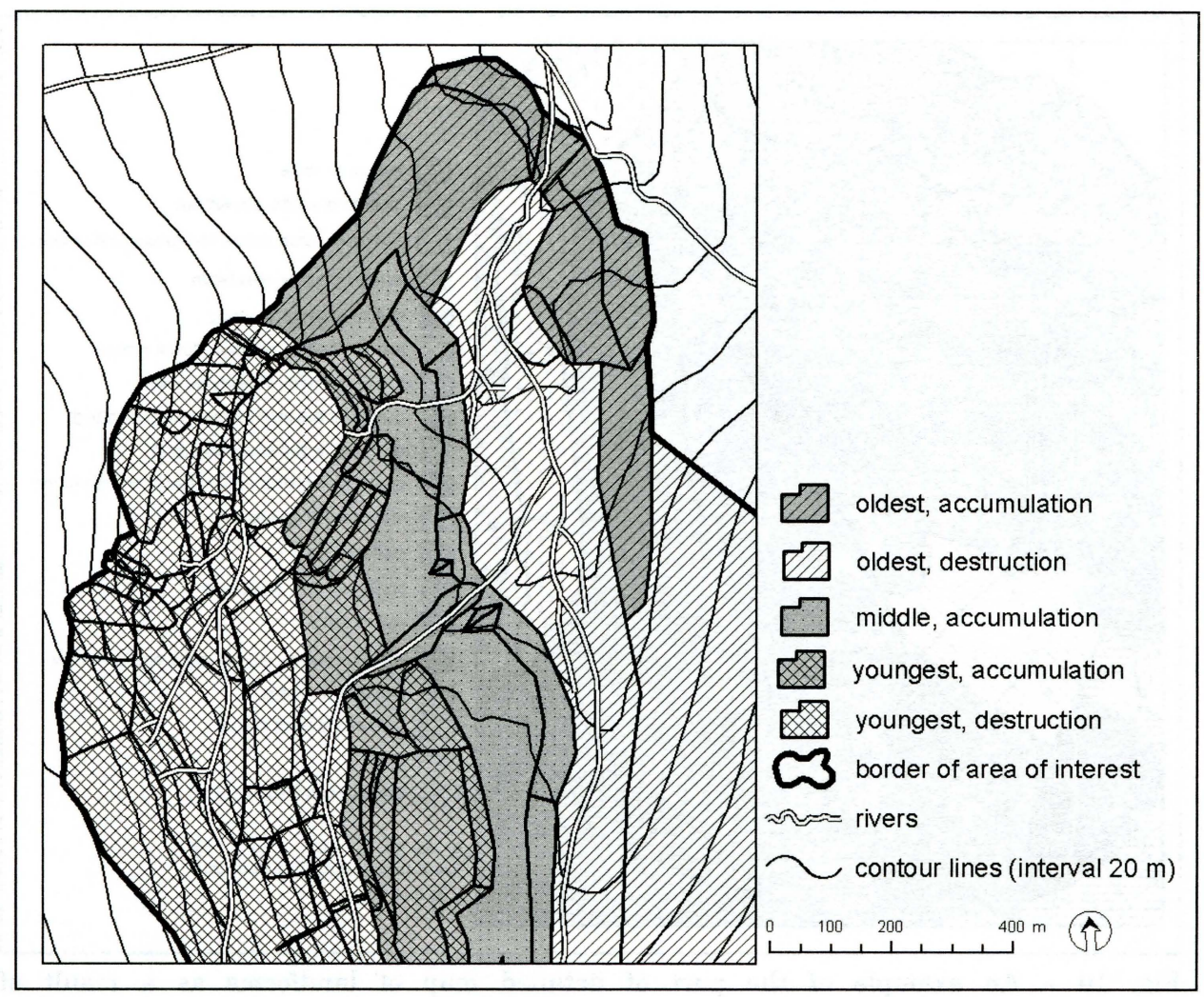

Fig. 9 - Morphochronological map of the surroundings of Prášilské jezero (lake).

furrows' have been investigated as geomorphological varieties of the corries in the surroundings of Prášilské jezero (lake) (Mentlík 2004, Mentlík 2005a).

The information about the type of the process or the stage of evolution of the particular form could be registered in the Geodatabase as an attribute (Fig. 4 - table of genetic characteristics). The processes could be fossil or present-day. Active and passive forms were distinguished according to the presence or absence of present-day morphogenetically relevant processes in the particular form (see Mentlík 2004, 2005b).

Analysis of morphochronology: we investigated the age of particular morphogenetical forms in this stage of geomorphological analysis by using various methods of relative dating (Schmidt hammer test, analysis of roughness of rock surfaces etc.) and numerical dating (AMS and conventional radiocarbon dating) (e.g. Mentlík et al. 2005 or Bř́izová \& Mentlík 2005). The aim of this phase of geomorphological analysis was to postulate particular geomorphosystems for each stage of development of the georelief. The morphochronological map is the output of this phase in GmIS (Fig. 9).

Summary of geomorphological analysis (postulation of hypothesis for development of the area of interest): The aim of this penultimate stage of geomorphological analysis is to postulate the hypothesis for the genesis of the area under concern. This hypothesis should cover all five main aspects of georelief (Demek ed. 1972) - investigation of morphology and morphometric characteristics by means of elementary forms of relief, morphogenesis by 


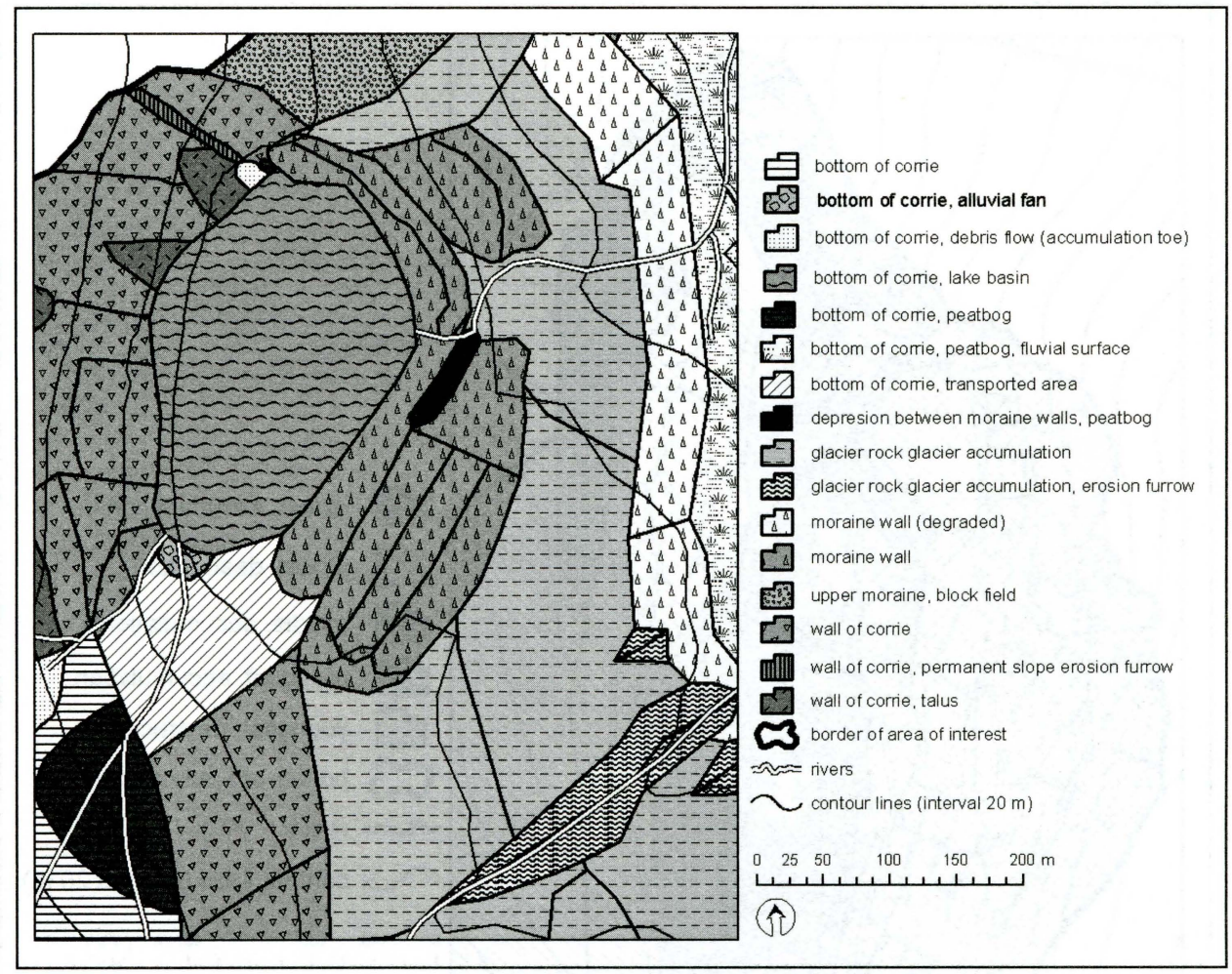

Fig. 10 - An example of the part of detailed map of landforms as a result of geomorphological analysis

means of particular morphogenetical forms and morphodynamics by means of investigation of present-day geomorphic processes, which define geomorphological varieties in our case. Morphochronology is expressed by particular geomorphosystems of development of georelief in the area of interest and morphochronological maps (Fig. 10).

Verification or falsification of the hypothes: The hypothesis has to be verified or falsified by some independent and significant methods in the last stage of geomorphological analysis. A wide range of various methods is used for this. However, geological methods are the most common (for example scanning electron microscopy, analysis of heavy minerals, X-ray analysis of clay minerals, and other particularly sedimentological methods such as analysis of shape and roundness of clasts etc.), even though some biological methods (mainly pollen analysis) are also frequently used. It is necessary to stress that an interdisciplinary approach is highly important in this stage of geomorphological analysis. If the results of this parallel research were not in agreement with the results of the geomorphological analysis, it would be necessary to repeat the whole process again trying to find the reason (or reasons) for the discrepancy.

The analysis of shape and roundness of clasts as well as scanning electron microscopy were used in this phase in the surroundings of Prášilské jezero (lake) (Mentlík et al. 2005). Finally, the results of geomorphological analysis and the results of the other methods were connected and the final hypothesis for the development of the area under concern was postulated. 
In GmIS the results of the research are connected with particular elementary forms or geomorphological kind respectively. The hypothesis of genesis of the particular area could be tested owing to this spatial connection.

\section{Conclusions}

The physical model of the geomorphological database based on the logical model postulated in Minár et. al. (2005) is presented in this paper. The concept is derived from the comprehensive approach to geomorphological information system creation (Barsch \& Dikau 1989; Dikau 1992; Minár 1996) based on layer structure of the database and fundamental considerations of geomorphological space, time, and basic data in mutual relations. However, the model is open, allowing incorporation of particular approaches to geomorphological (geomorphic) information system creation focused on solving specific geomorphological problems (e.g. Zhu, H. \& Schneider 1999; Tachikawa et al. 2003).

Our physical model is composed of three major groups of layers: adopted, basic and special layers (creation of special geomorphological layers is not discussed). The model structure allows easy and safe data handling by setting up relationships and topologies. Relationships maintain attribute integrity among layers and tables. Topologies maintain spatial integrity of the spatial data by rules. There can also be marked exceptions from rules for special cases. A well defined database structure also allows a geomorphologist to perform many geomorphological analysis steps using common GIS tools. Special analysis steps can be programmed in various languages. ESRI ModelBuilder and Python were used in GmIS.

The concept of geomorphological analysis in GmIS was used in research of the surroundings of Prášilské jezero (lake) in the Šumava Mts. (Czechia). The layer of elementary forms (Minár 1996), which are defined according to their morphology and morphometric characteristics, is postulated as the core of the analysis. All data are connected with this layer and subsequently provide the information for particular analyses. However, morphogenetical forms (defined according to their genesis) are used as the fundamental units during the geomorphological analysis. Seven steps of geomorphological analysis are suggested in the frame of the presented GmIS with the following main advantages:

- The analysis uses a uniform approach for delimitation of landforms.

- The analysis covers the whole area of interest and deals with all parts of the area equally.

- The process is reversible and it is possible to repeat it and to investigate particular steps separately. The geomorphological analyses provide partial outputs, which can be interpreted separately.

- The process provides opportunity for verification of the hypothesis of evolution of the area of interest in an exact way (the verification of the hypothesis is in fact a part of the analysis).

In the future, building of GmIS will continue. New tools and modules, intended for construction of various special geomorphological layers, will be added. The proposed design of the GmIS can also be modified - the creation of GmIS in regions with different types of georelief (and with different data availability) will probably require a slightly different structure to the system. Only experiences from several completed systems can lead to the creation of 
a more universal design of GmIS. Thus the GmIS should become a robust tool for geomorphological research.

\section{References:}

ARCTUR, D., ZEILER, M. (2004): Designing Geodatabases - Case studies in GIS Data Modeling, Redlands, California, ESRI Press, 393 pp.

BARSCH, D., DIKAU, R. (1989): Entwicklung einer Digitalen Geomorphologischen Basiskarte (DGmBK). Geo-informations systeme, 2, No. 3, pp. 12-18.

BŘÍZOVÁ, E., MENTLIK, P. (2005): Preliminary results of geomorphological research and pollen analysis in the Stará jímka area (the Bohemian Forest). In: Rypl, J. (ed.): Geomorfologický sborník 4. Jihočeská univerzita v Českých Budějovicích, České Budějovice, pp. 155-158.

DEMEK, J. (ed.) (1972): Manual of Detailed Geomorphological Mapping. Academia, Praha, $344 \mathrm{p}$.

DIKAU, R. (1992): Aspects of constructing a digital geomorphological base map. Geologisches Jahrbuch, A122, pp. 357-370.

ESRI. Case Studies Data Models - ESRI Support [online]. [cit. 2005-04-13]. $<$ http://support.esri.com/index.cfm?fa=downloads.dataModels.caseStudies $>$.

JEDLICKA, K. (2005): Konvence $\mathrm{v}$ pojmenovávání geodatabáze (Geodatabase naming conventions). ArcRevue. Jaro 2005, No. 1, pp. 25-26.

KUSENDOVÁ, D. (2000): Digitálna legenda pre geomorfologické mapy. Kartografické listy. (Digital legend for geomorphological maps) 8, s. 45-54.

MENTLÍK, P. (2004): Příspěvek k poznání recentních geomorfologických procesů v okolí Prášilského jezera. (Contribution to research of recent geomorphological processes in the surroundings of Prášilské jezero lake). Silva Gabreta, 10, pp. 9-30.

MENTLÍK, P. (2005a): From 'catena' to geomorphological system - an approach to study of present-day geomorphological forms and processes. Geomorphologia Slovaca, 5, No. 1, pp. 55-64.

MENTLÍK, P. (2005b): Zhodnocení stavu geomorfologických výzkumů v okolí Prášilského jezera a jezera Laka a návrh dalšího postupu výzkumných prací. (Evaluation of state of geomorphological research in the surroundings of Prášilské jezero (lake) and Laka Lake and proposal of the prospective research). Dissertation (proposal). Univerzita Komenského v Bratislave, Prŕrodovědecká fakulta, katedra fyzické geografie a geoekológie, Bratislava, $70 \mathrm{p}$.

MENTLÍK, P., LISÁ, L., BŘÍZOVÁ, E. (2005): Glacial forms and development of the landscape during Pleistocene and Holocene in the vicinity of Prášilské Lake (Bavarian Forest, Czech Republic). In: Gutieréz, F., Gutieréz, M., Desir, G., Guerrero, J., Lucha, P., Marín, C., García-Ruiz, J. M. (ed.): 6th International Conference on Geomorphology, Abstract volume. Zaragoza. Spain, $10 \mathrm{p}$.

MINÁR, J. (1996): Niektoré teoreticko-metodologické problémy geomorfológie vo väzbe na tvorbu komplexných geomorfologických máp (Some Theoretical and Methodological Problems of Geomorphology Associated with the Creation of Complex Geomorphological Maps). Acta Facultatis Rerum Naturalium Universitatis Comenianae, XXXVI, pp. $7-125$.

MINÁR, J., MENTLÍK, P., JEDLIČKA, K., BARKA, I. 2005. Geomorphological information system - idea and options of practical implementation, Geografický časopis, 57, No. 3, pp. 247-266.

TACHIKAWA, Y., SHIIBA, M. \& TAKASAO, T. (2003): Development of a basin geomorphic information system using a TIN-DEM data structure, in chapter 3, In: Lyon, J. G. GIS for water resources and watershed management, Taylor and Francis, London, pp. 25-37.

TUCEK, J. (1998): Geografické informační systémy: principy a praxe (Geographical Information Systems: Principles and Practice). 1. vyd. Computer Press, Praha, 426 p.

URBÁNEK, J. (2000a): Geomorfologická analýza: hPadanie systému. (Geomorphological analysis: search for system). Geografický časopis, Bratislava, 52, No. 3, pp. 197-210.

URBÁNEK, J. (2000b): Geomorfologická analýza: hPadanie pravdy. (Geomorphological analysis: search for truth). Geografický časopis, Bratislava, 52, No. 4, pp. 291-302.

VOŽENÍLEK, V., KIRCHNER, K., KONEČNÝ, M., KUBÍČEK, P., LÉTAL, A., PETROVÁ, A., ROTHOVÁ, A., SEDLÁK, P. (2001): Integrace GPS/GIS v geomorfologickém 
výzkumu. (Integration of GPS/GIS to geomorphological research). Univerzita Palackého v Olomouci, Olomouc. $185 \mathrm{p}$.

ZHU, H., SCHNEIDER, K. (1999): Flat feature processes from triangulated irregular networks for hydrological modeling. In International Conference on GeoComputation, 4th, Fredericksburg VA, Mary Washington College, 25-28 July, GeoComputation 99: http://www.geovista.psu.edu/geocomp/geocomp99/Gc99/091/gc_091.htm.

\section{Software, programming languages and other tools:}

The following software was used for this project:

ArcGIS Desktop, ArcINFO license - for implementing both logical and physical data model. ESRI Diagrammer and Microsoft Visio - for ESRI Geodatabase reverse engineering.

GRASS - for DEM interpolation.

ModelBuilder and Python - for geomorphological analysis process diagrams.

VisualBasic for Applications and ArcObjects - for CAD data conversion to GRASS.

\section{Shrnutí}

\section{GEOMORFOLOGICKÝ INFORMAČNÍ SYSTÉM: FYZICKÝ MODEL A MOŽNOSTI GEOMORFOLOGICKÉ ANALÝZY}

Předkládaný článek navazuje na naši předešlou studii Geomorfologický informační systém - základní myšlenky a možnosti praktického využití (Minár et al. 2005). Geomorfologický informační systém (GmIS) je speciální typ Geografického informačního systému (GIS), který je zaměřen na sběr, správu a analýzu geomorfologických dat. Cílem článku je prezentovat fyzický model GmIS a případovou studii jeho implementace z okolí Prášilského jezera na Sumavě. Studie prezentuje aplikaci geomorfologické analýzy a interdisciplinárního výzkumu a jejich integraci v GmIS, při využití jeho analytických a databázových funkcí. Je zdůrazněna potřeba stabilního, přesného a flexibilního modelu GmIS pro geomorfologické účely.

Nejprve je představen již dříve definovaný logický model, (Minár et al. 2005), který je založen na třech logických skupinách vrstev:

- převzaté vrstvy - vrstvy $\mathrm{z}$ vnějších zdrojů

- základní vrstvy - obsahující data určovaná požadavky geomorfologického výzkumu, jež jsou odvozována z převzatých vrstev nebo získávána geomorfologickým mapováním; jádro systému tvoří vrstva elementárních forem reliéfu (cf Minár 1996)

- speciální vrstvy - data odvozená z prvních dvou skupin vrstev za využití speciálních geomorfologických metodických postupů (např. morfostrukturní analýza, komplexní geomorfologická analýza atd.).

V příspěvku je dále popisován fyzický model GmIS, a to na úrovni jednotlivých vrstev (obr. 4). Detailně je popisováno jádro fyzického modelu - vrstva elementárních forem reliéfu a atributové vazby jednotlivých forem na tabulky morfometrických charakteristik (výškové, sklonové, orientace sklonu svahu, vrstevnicová a profilová křivost) a morfogenetických charakteristik (tabulka 1). Popsány jsou i možnosti využití topologických vazeb na př́íkladu vazeb mezi vrstvami elementárních forem a jejich hranicemi.

Popis struktury modelu pak přechází v popis procesů, které v něm probíhají. Je navržen způsob technické realizace automatizace procesů v GmIS s využitím grafického i textového (objektově orientovaného) vývojového prostředí.

Geomorfologická analýza v GmIS je prezentována na př́ikladu z okolí Prášilského jezera na Šumavě. Koncept geomorfologické analýzy vychází z prací Urbánka $(2000 a, b)$. Tento základní koncept je doplněn a transformován tak, aby umožňoval využití v GmIS. Takto definovaná geomorfologická analýza se skládá ze sedmi základních částí (tabulka 2): (identifikace, diferenciace - dále rozdělené do tří fází, systematizace, analýzy recentních geomorfologických procesů, analýzy morfochronologie, shrnutí geomorfologické analýzy spolu se stanovením hypotézy vývoje zkoumaného území a verifikace této hypotézy). Základem geomorfologické analýzy v GmIS je vrstva elementárních forem reliéfu. K jednotlivým elementárním formám, jež jsou definovány na základě jejich morfologie a morfometrie, jsou připojována konkrétní data získaná v průběhu prováděných analýz.

Pro potřeby geomorfologické analýzy, která se zabývá zejména genezí jednotlivých forem, jsou na atributovém základě vymezovány tzv. morfogenetické formy vznikající spojením elementárních forem reliéfu na základě jejich geneze. Tato geomorfologická individua 
v podstatě odpovídají tradičním geomorfologickým formám. Verifikace hypotézy vývoje reliéfu zájmového území je prováděna různými (zejména geologickými) metodami.

Tvorba GmIS bude pokračovat i v budoucnu, zejména by měly být připraveny speciální nástroje a moduly umožňující zautomatizování některých krokủ geomorfologických analýz. U celého systému je třeba počítat s úpravami pro specifické typy reliéfu.

Obr. 1 - Zobrazení základní struktury logického modelu v projektu aplikace ArcMap a vymezení zájmového území v okolí Prášilského jezera.

Obr. 2 - Legenda k diagramům reverzního inženýrství podle Artur \& Zeiler (2004); vytvořeno nástrojem ESRI Geodatabase Diagrammer a aplikací Microsoft Visio.

Obr. 3 - Fyzický model; přehled geomorfologických vrstev. Reverzní inženýrství vytvořené nástrojem ESRI Geodatabase Diagrammer a aplikací Microsoft Visio.

Obr. 4 - Fyzický model; detail elementárních forem a souvisejících tř́íd. Reverzní inženýrství vytvořené nástrojem ESRI Geodatabase Diagrammer a aplikací Microsoft Visio.

Obr. 5 - Fyzický model; detail topologie mezi elementárními formami a jejich hranicemi. Reverzní inženýrství vytvořené nástrojem ESRI Geodatabase Diagrammer a aplikací Microsoft Visio.

Obr. 6 - Charakteristika sklonu svahu. Schéma v ModelBuilder a ukázka jádra kódu v jazyce Python. Vytvořeno v ModelBuilder v ArcGIS.

Obr. 7 - Ukázka části primární geomorfologické mapy okolí Prášilského jezera.

Obr. 8 - Ukázka sekundární geomorfologické mapy okolí Prášilského jezera.

Obr. 9 - Ukázka části morfochronologické mapy okolí Prášilského jezera.

Obr. 10 - Ćást podrobné geomorfologické mapy okolí Prášilského jezera.

(Pavel Mentlik is with University of West Bohemia in Pilsen, Faculty of Education, Department of Geography, Veleslavinova 42, 306 14, Pilsen, Czechia; pment@kge.zcu.cz. Karel Jedlicka is with University of West Bohemia in Pilsen, Faculty of Applied Sciences, Department of Mathematics, Geomatic section, Univerzitni 22, 306 14, Pilsen, Czechia; smrcek@kma.zcu.cz. Jozef Minár is with Comenius University in Bratislava, Faculty of Natural Sciences, Department of Physical Geography and Geoecology, Mlynská dolina, 842 15, Bratislava, Slovakia; minar@fns.uniba.sk. Ivan Barka is with Comenius University in Bratislava, Faculty of Natural Sciences, Department of Landscape Ecology, Mlynská dolina, 842 15, Bratislava, Slovakia; barka@fns.uniba.sk.)

Arrived to the editorial board on November 4, 2005 